Jurnal Keuangan dan Perbankan, Vol.20, No.1 Januari 2016, hlm. 1-9

Terakreditasi SK. No. 040/P/2014

http://jurkubank.wordpress.com

\title{
PENGARUH KINERJA PERUSAHAAN, CORPORATE GOVERNANCE, DAN KARAKTERISTIK EKSEKUTIF TERHADAP KOM PENSASI EKSEKUTIF
}

\author{
Suherman \\ Yoseph Y. P. Pardede \\ Umi Mardiyati \\ Jurusan M anajemen Fakultas Ekonomi Universitas Negeri Jakarta
}

\begin{abstract}
The objectives of this research are1) to examinethe effect of firm performance on executive compensation, 2)to investigatethe effect of corporategovernance on executivecompensation, and 3) to find out the effect of executivecharacteristics on executivecompensation. Sample of this research consists of 46 firms (157 observations) listed on Kompas100 index between 2010 and 2013. Controlling for firm size, theresults show that 1)RO A has positiveand significant effect on executivecompensation, but N PM and T obin's Q do not, 2)institutional ownership and independent commissioner do not havesignificant effect on executive compensation, and 3)executiveage and gender do not havesignificant effect on executivecompensation.
\end{abstract}

Kata Kunci: K ompensasi, karakteristik eksekutif, corporategovernance

Pemegang saham (stockholders) seringkali memusatkan perhatiannya terhadap pemberian kompensasi eksekutif dalam perusahaannya. Alasannya adalah kompensasi yang diberikan kepada eksekutif seringkali tidak sebanding dengan hasil yang didapatkan perusahaan dan kontribusi yang diberikan oleh eksekutif tersebut sehingga diperlukan tindakan untuk mengevaluasi hal ini (Sands, 2014). Seorang eksekutif sering kali menerima jumlah kompensasi yang luar biasa tinggi untuk kinerja yang biasa-biasa saja (Boone dan Kurtz, 2007). Sudarsono (2002) mengemukakan bahwa dengan mengaitkan kompensasi eksekutif dengan kinerja perusahaan, maka para eksekutif ini akan lebih termotivasi untuk mengambil keputusan-keputusan yang menguntungkan dan yang bisa memaksimalkan nilai pemegang saham.

Bizjak, et al . (2013) menyatakan bahwa besarnya kompensasi yang diterima eksekutif dalam sebuah perusahaan memiliki hubungan dengan kinerja perusahaan atau dengan kata lain seorang eksekutif dalam perusahaan tersebut akan mendapatkan peningkatan kompensasi disertai dengan meningkatnya nilai (value) perusahaan yang merupakan

Korespondensi dengan Penulis:

Suherman:

Email: - 


\section{Jurnal Keuangan dan Perbankan | KEUANGAN}

Vol. 20, N 0.1, Januari 2016: 1-9

hasil dari kinerja yang baik pula. Parthasarathy, et al. (2006) mengemukakan bahwa kepemilikan saham oleh institusi (institutional ownership) me miliki hubungan yang positif dengan kompensasi eksekutif. Kepemilikan institusional ini mempunyai peran dan fungsi yang sama dengan jajaran direktur independen yang ada dalam perusahaan dengan melakukan pengamatan. Sehingga bisa dikatakan bahwa kepemilikan institusional memiliki pengaruh yang positif terhadap pemberian kompensasi terhadap eksekutif dalam sebuah perusahaan. Komposisi dewan komisaris independen memiliki pengaruh terhadap kompensasi eksekutif dalam sebuah perusahaan. Bukti empiris dipaparkan oleh Ayadi dan Boujèl bène (2013) bahwa keberadaan komisaris independen dalam dewan direksi perusahaan dapat memberikan pengaruh kepada perusahaan dalam menetapkan besarnya kompensasi eksekutif perusahaan tersebut.

Xiao, et al. (2013) menyatakan bahwa di perusahaan-perusahaan juga terdapat ketidak-setaraan dalam pemberian kompensasi terhadap CEO. Hal ini bisa dilihat dari adanya pemberian kompensasi yang diberikan kepada CEO prialebih tinggi daripada CEO wanita walaupun CEO wanita memiliki pendidikan yang lebih tinggi dan lebih senior dalam suatu perusahaan. Artinyagender juga mempunyai pengaruh dalam kompensasi eksekutif. Usia mempengaruhi produktivitas tenaga kerja (N uh, 2013). Ia mengemukakan argumennya bahwa tenaga kerja yang lebih tua memiliki pengalaman lebih lama sehingga menjadi lebih ahli dalam menyelesaikan suatu pekerjaan. Dengan begitu seorang eksekutif yang lebih tua cenderung lebih terhindar dari kelalaian sehingga dapat melakukan keputusan yang tepat menyangkut perusahaan yang dipimpinnya. Ukuran perusahaan mempengaruhi besaran kompensasi yang diterima oleh eksekutif dalam sebuah perusahaan (Gabaix, et al . 2013). Tanggung jawab yang dipikul oleh seorang eksekutif dalam sebuah perusahaan dan ukuran perusahaan itu sendiri mempunyai hubungan yang berbanding lurus dimana semakin besar ukuran perusahaan itu, semakin besar pula tanggung jawab yang dipikul oleh eksekutif tersebut.

Penelitian mengenai kompensasi eksekutif lebih banyak dilakukan di negara-negara maju. Ini dikarenakan semakin meningkatnya penerapan corporate governance dan kemudahan dalam mendapatkan data mengenai kompensasi eksekutif dari perusahaan-perusahaan yang terdapat di bursa saham (Vidyatmoko, et al. 2013). Sedangkan untuk negara berkembang seperti Indonesia, relatif sedikit penelitian mengenai kompensasi eksekutif. Darmadi (2011) mengungkapkan bahwa struktur kompensasi dari perusahaan yang listing di Indonesia relatif dijaga kerahasiaannya. Sehingga hanya sedikit informasi untuk mengetahui faktor-faktor apa sajayang mempengaruhi kompensasi eksekutif. Kami melakukan penelitian ini untuk mengetahui apakah kinerja perusahaan (dengan proksi ROA, NPM, dan Tobin's Q), corporategovernance (dengan proksi institutional shareholding dan proporsi komisaris independen), dan karakteristik eksekutif (dengan proksi gender dan usia) berpengaruh terhadap kompensasi eksekutif. Hasil penelitian kami menunjukkan bahwa hanya kinerja perusahaan (yang diukur dengan ROA) memiliki pengaruh signifikan terhadap kompensasi eksekutif.

Besarnya kompensasi yang diterima eksekutif adalah berbeda antar perusahaan (Diaz dan Espa, 2008). Besarnya kompensasi ini umumnya didasarkan pada informasi keuangan yang dike luarkan perusahaan (Scott, 2003). Teori keagenan mengungkapkan bahwa kinerja perusahaan berpengaruh positif kepada remunerasi. Devi (2012), Rashid (2013), Sun et al (2013), Anggraini et al (2014), dan Bizjak et al (2014) menyatakan bahwa pembayaran yang diterima oleh eksekutif sebuah perusahaan memiliki hubungan yang positif dengan kinerja perusahaan. N amun Suherman, et al. (2015) menemukan bahwa kinerja perusahaan yang diukur dengan Tobin's Q tidak memiliki pengaruh signifikan terhadap kompensasi yang diterima eksekutif. 


\section{Pengaruh Kinerja Perusahaan, Corporate Governance, dan Karakteristik Eksekutif terhadap Kompensasi Eksekutif}

Suherman, Yoseph Y. P. Pardede, \& Umi Mardiyati

Kepemilikan institusi adalah salah satu pengukuran dalam mekanisme corporategovernance dan dibutuhkan untuk membantu menentukan besarnya kompensasi yang diterima oleh eksekutif dalam sebuah perusahaan (Rahmawati 2010). Pemberian kompensasi dimaksudkan untuk mengatasi masalah keagenan (Nazir, 2014). Pengawasan yang tinggi oleh institusi dapat berdampak pada kemampuan eksekutif untuk mempengaruhi kontrak kompensasi eksekutif. Lee dan Chen (2011) dalam penelitiannya menyimpulkan bahwa kepemilikan saham yang dimiliki sebuah institusi memiliki hubungan yang positif terhadap kompensasi yang dibayarkan kepada CEO. Croci et al (2012) dalam penelitiannya menemukan bahwa kepemilikan saham yang dimiliki oleh institusi memiliki pengaruh yang positif terhadap struktur pembayaran kompensasi kepada CEO termasuk institusi asing. Ozdemir dan Upneja (2012) menemukan proporsi dewan komisaris independen memiliki hubungan yang positif dengan kompensasi yang diterima chief executive officer (CEO).

Komisaris independen adalah salah satu karakteristik dewan komisaris dalam sebuah perusahaan (Andarini, 2012). Dalam sebuah perusahaan terdapat komite yang menentukan besaran kompensasi atau remunerasi direksinya dan komiteitu harusterdiri dari komisarisindependen dengan tujuan untuk menjaga independensi dan objektivitas. Keberadaan komisaris independen dibutuhkan dalam perusahaan untuk mengontrol dan mengawasi tindakan-tindakan direksi. N ourayi et al (2012) mengungkapkan bahwa persentase komisaris independen dalam suatu perusahaan memiliki hubungan yang signifikan terhadap kompensasi yang diterima oleh CEO. Darmadi (2011) menyatakan bahwa perusahaan yang lebih kecil sering menghabiskan bagian yang lebih besar dari sumber daya keuangan mereka dalam membayarkan kompensasi kepada dewan pengurus perusahaan. Conyon dan $\mathrm{He}$ (2012) menemukan bukti empiris bahwa tata kelola internal perusahaan dapat dilihat dan diukur dari jumlah outside direc- tors' dalam jajaran dewan pengurus perusahaan tersebut. A yadi dan Boujèl bène (2013) menyatakan bahwa keberadaan dewan pimpinan perusahaan independen memiliki hubungan yang positif dan signifikan terhadap kompensasi yang diterima oleh CEO suatu perusahaan dan dapat membantu perusahaan dalam menentukan tingkat remunerasi eksekutif dalam perusahaan tersebut.

Proporsi jumlah wanita pada top management perusahaan masih sangat kecil jumlahnya (Nathania, 2014). Variasi gender dalam perusahaan-perusahaan besar semakin berkembang ditandai dengan jumlah wanita yang berperan dalam perusahaan dengan latar belakang yang berbedabeda (N athania, 2014). Xiao et al (2013) mengungkapkan bahwa gender menjadi penentu penting dalam pembayaran kompensasi pada perusahaanperusahaan di China. Faktanya ditemukan bahwa perusahaan-perusahaan tersebut cenderung memberi bonus (premium pay) terhadap CEO pria sekalipun CEO wanita lebih senior dan berpendidikan lebih tinggi. Lin dan Lu (2014) menyatakan bahwa gender dari CEO berhubungan secara signifikan dengan kompensasi kas CEO tapi tidak dengan kompensasi total kas CEO. Dijelaskan bahwa kompensasi kas yang diterima CEO pria lebih tinggi dari CEO wanita.

Usia CEO sangat erat kaitannya dengan kemampuan yang dimilikinya dan dapat mempengaruhi perusahaan dal am menentukan besarnya kompensasi yang diterima (Lin dan Lu, 2014). N ourayi et al (2012) mengungkapkan bahwa usia dari CEO memiliki hubungan yang positif terhadap pemberian insentif yang merupakan bagian dari kompensasi yang diterima. Colpan dan Yoshikawa (2012) dalam penelitiannya menunjukkan bahwa terdapat pengaruh usia dewan direksi suatu perusahaan terhadap kompensasi yang diberikan. Anggraini et al (2014) dalam penelitiannya menyimpulkan bahwa usia dewan direksi berpengaruh terhadap pemberian kompensasi kepada dewan direksi di perusahaan jasa perbankan yang go public di Indonesia. Wang et al (2013) menjelas- 


\section{Jurnal Keuangan dan Perbankan | KEUANGAN}

Vol. 20, N 0.1, Januari 2016: 1-9

kan bahwa seorang eksekutif tidak membangun kekuatan dan pengaruh yang dia punya dalam waktu singkat. Kesimpulan dari penelitian ini adalah seorang eksekutif dengan usia yang lebih tua mendapatkan kompensasi yang lebih besar. Hal ini menunjukkan usia eksekutif suatu perusahaan berkaitan dengan pengalaman dan kemampuan yang dimiliki dalam mempengaruhi dewan pengurus perusahaan dalam memberikan kompensasi. Semakin bertambahnya usia tentu pengetahuan dan kemampuan yang dimilikinya akan semakin bertambah disertai berbagai macam tantangan dalam dunia bisnisyang pernah ialewati akan menjadikannya sebagai pengalaman di masa mendatang untuk bisa mengelola dan memimpin perusahaan dengan baik.

\section{METODE PENEUTIAN}

Sampel yang digunakan adalah perusahaan yang terdaftar di Indeks Kompas100. Periode penelitiannya adalah tahun 2010-2013. Jumlah perusahaan yang terdaftar di Indeks Kompas100 pada periode tersebut sebanyak 128 perusahaan. Sebanyak 75 perusahaan tidak memiliki data lengkap mengenai kompensasi dan 7 perusahaan yang memiliki laba negatif. Sehingga sampel akhir yang digunakan adalah sebanyak 46 perusahaan. Penelitian ini menggunakan analisis data panel tidak seimbang (unbalance panel data). Data kompensasi diperoleh dari A nnual Report yang diterbitkan oleh setiap perusahaan. M etode analisis yang digunakan di dalam penelitian ini adalah regresi pooled least square (PLS). Data diolah dengan menggunakan Eviews 7.0. Persamaan yang diuji dalam penelitian ini adalah sebagai berikut:

$$
\begin{aligned}
& C O M P_{i t}=\beta_{0}+\beta_{1} R O A_{i t}+\beta_{2} \Delta \text { ROA }_{i t}+\beta_{3} N P M_{\text {it }} \\
& +\beta_{4} \Delta N M_{i t}+\beta_{5} T Q_{i t}+\beta_{6} \Delta T_{\text {Tit }}+\beta \text { IIN } D_{i t}+\beta_{8} I N S_{i t} \\
& +\beta{ }_{9} G_{\text {ender }}{ }_{i t}+\beta_{10} A \mathrm{AE}_{i \mathrm{t}}+\beta_{11} \mathrm{LnSIZE}_{i t}+\varepsilon_{i t}
\end{aligned}
$$

\section{Keterangan:}

COM P: meliputi gaji, tunjangan, dan bonus, ROA: Return on Assets, NPM : Net Profit Margin, TQ: Tobin's Q, "ROA: Incremental ROA, “NPM: Incremental NPM, "TQ: Incremental Tobin's Q, IND: Proporsi Komisaris
Independen, INS: Persentase Kepemilikan saham oleh Institusi, Gender: Jenis Kelamin yang diukur dengan angka 1 yang berarti wanita dan 0 yang berarti laki-laki, AGE: Usia, dan SIZE: log natural aset

\section{HASIL \& PEMBAHASAN}

Padapenelitian ini, kinerja perusahaan diukur menggunakan ROA, “ ROA, NPM, “ NPM, Tobin's Q dan “ Tobin's Q. Pada Tabel 1 persamaan I, ROA sebagai proksi dari kinerja perusahaan menunjukkan pengaruh yang positif dan signifikan terhadap kompensasi eksekutif. Hal ini terlihat dari nilai koefisien sebesar 0,03 dan probabilitas t-hitung sebesar 2,90. Hasil ini sama dengan penelitian yang dilakukan oleh Devi (2012) yang menyatakan bahwa pengukuran kinerja perusahaan dengan ROA (Return on A sset) berpengaruh positif signifikan terhadap kompensasi eksekutif. Hal ini dapat terjadi karena bonus yang diberikan perusahaan kepada eksekutif tergantung dari profit yang diperoleh perusahaan, artinya semakin besar ke untungan yang diperoleh perusahaan, semakin be sar pula bonus yang diterima oleh eksekutif se hingga jumlah kompensasinya pun meningkat (Rahmawati, 2010). Incremental ROA (“ ROA) yang diukur dengan selisih ROA tahun sekarang dengan ROA tahun sebelumnya memiliki pengaruh negatif dan signifikan terhadap kompensasi eksekutif. Pada persamaan I, " ROA memiliki koefisien se besar -0.01 dan probabilitas t-hitung sebesar $-2,71$. Hal ini sama yang diperoleh Partasarathy (2006) dan Bennet (2010) menyatakan bahwa Incremental ROA (" ROA) memiliki hubungan yang signifikan terhadap kompensasi eksekutif karena adanya perubahan tingkat pengembalian aset akan menjadi bahan pertimbangan suatu perusahaan dalam menentukan besarnyakompensasi yang diterima oleh eksekutif dan hubungan " ROA dengan kompensasi eksekutif negatif karena dalam teori keagenan, perusahaan yang sedang mengalami penurunan kinerja, maka strategi manajemen akan menaikkan kompensasi finansial yang diberikan dewan direksi (eksekutif perusahaan) dalam rangka meningkatan kinerja perusahaan tersebut (Diaz dan Espa, 2008). 
Pengaruh Kinerja Perusahaan, Corporate Governance, dan Karakteristik Eksekutif terhadap Kompensasi Eksekutif

Suherman, Yoseph Y. P. Pardede, \& Umi Mardiyati

Tabel 1. Hasil Regresi Random Effect

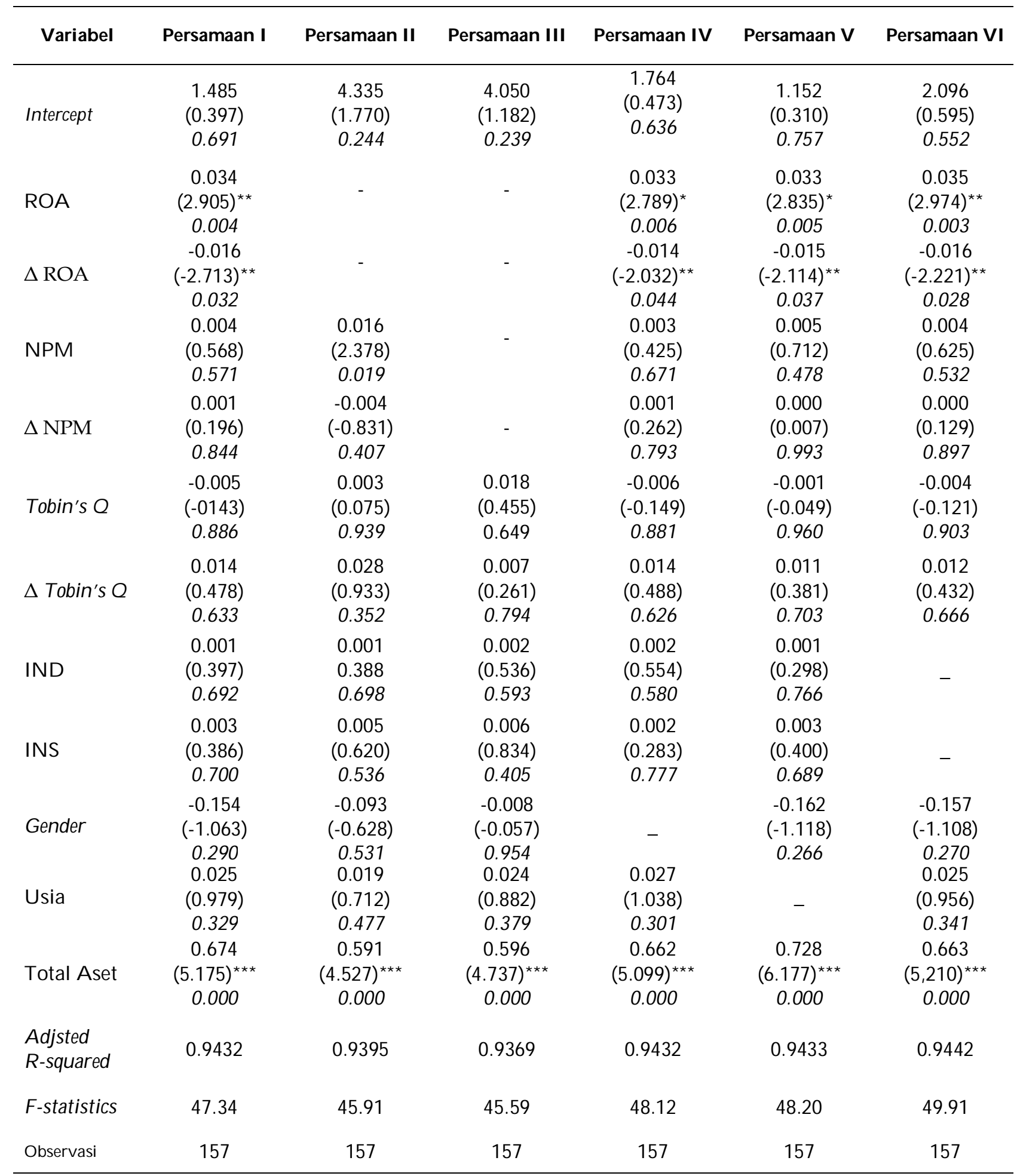

Data diolah peneliti. Tanda *, **, dan *** menandakan signifikan pada level 10\%, 5\%, dan $1 \%$. Angka dalam kurung adalah nilai t-stat. Angka yang tercetak miring (dibawah t-stat) ialah nilai $p$-value. 


\section{Jurnal Keuangan dan Perbankan | KEUANGAN}

Vol. 20, N 0.1, Januari 2016: 1-9

Berikutnya NPM sebagai proksi lainnya dari kinerja perusahaan pada persamaan I memiliki pengaruh positif dan tidak signifikan terhadap kompensasi eksekutif dalam sebuah perusahaan. $\mathrm{Hal}$ ini terbukti dari nilai koefisien sebesar 0,004 sedangkan p-valuenya menunjukkan probabilitas sebesar 0,57. Hal ini terjadi, karena selisih dari NPM tahun sekarang dengan tahun sebelumnya tidak memiliki pengaruh positif signifikan terhadap kompensasi eksekutif. Hasil ini juga sama yang diperoleh Partasarathy, et al . (2006) dan Suherman et al. (2015), dikarenakan penelitian yang memasukkan perusahaan dengan berbagai jenis sektor industri yang berbeda-beda sebagai sampel penelitian. Lalu incremental NPM (“ NPM) pada persamaan I memiliki pengaruh yang positif dan tidak signifikan terhadap kompensasi eksekutif. Hal ini juga didapat oleh Partasarathy, et al. (2006) bahwa incremental NPM (“ NPM) dalam sebuah perusahaan tidak berpengaruh signifikan terhadap kompensasi eksekutif karena rasio ini tidak mencerminkan perusahaan dengan nilai incremental NPM (“ NPM) yang terus meningkat akan membuat perusahaan semakin tinggi pula membayarkan kompensasi yang diterima eksekutifnya dalam perusahaan tersebut.

Pada persamaan I, IV, V dan VI, Tobin's Q sebagai proksi untuk mengukur kinerja perusahaan terbukti memiliki pengaruh negatif dan tidak signifikan terhadap kompensasi eksekutif. Hasil yang sama diperoleh Suherman et al. (2015), dimana Tobin's Q memiliki hubungan tidak signifikan secara statistik. Hal ini menunjukkan bahwa tidak ada hubungan antara premi saham dengan tingkat kompensasi (compensation level). Dan juga incremental Tobin's Q (“ Tobin's Q) pada persamaan I, IV, V dan VI memperlihatkan hasil dengan nilai koefisien 0,$014 ; 0,014 ; 0,011$ dan 0,012 dan nilai probabilitas uji t-stat sebesar 0,63; 0,62; 0,70 dan 0,66 yang artinya incremental Tobin's Q (“ Tobin's Q) terbukti memiliki pengaruh positif dan tidak signifikan terhadap kompensasi eksekutif.
Variabel mekanisme corporate governance diukur dengan menggunakan proporsi komisaris independen (IND) dan kepemilikan institusi (INS). Pada persamaan I, IV dan V proksi INS terbukti memiliki pengaruh positif dan tidak signifikan terhadap kompensasi, hal ini terlihat dari nilai koefisien masing-masing persamaan yaitu sebesar 0,003 untuk persamaan I, 0,002 pada persamaan IV dan 0,003 pada persamaan $V$ dengan nilai probabilitas uji t-stat sebesar 0,70; 0,77 dan 0,68. Hasil yang sama juga diperoleh proporsi komisaris independen (IND) sebagai proksi kedua dari corporate governance, dimana persamaan I dan IV menunjukkan bahwa IND tidak terbukti memiliki pengaruh yang signifikan tetapi memiliki hubungan yang positif. $\mathrm{Hal}$ ini terlihat dari nilai koefisien sebesar 0,001; 0,002 dan 0,001 untuk persamaan I, IV dan $\mathrm{V}$ serta nilai probabilitas t-stat sebesar 0,69 (I) 0,58 (IV) dan 0,76 (VI) yang tidak menunjukkan pengaruh yang signifikan. Hal ini sama juga yang diperoleh Suherman et al. (2015) disebabkan karena mekanisme corporate governance pada perusahaan-perusahaan di Indonesia lebih efisien dalam menjalankan kewenangannya untuk melakukan monitoring, mere ka tidak mendorong untuk meningkatkan besarnya kompensasi yang akan diterima oleh para ekse kutif. Darmadi (2011) menyatakan hal yang sama bahwa kepemilikan institusi dan proporsi komisarisindependen didal am mekanismecorporategovernance didal am sebuah perusahaan-perusahaan di Indonesia tidak memiliki pengaruh terhadap besarnya kompensasi yang diterima oleh eksekutif. A kan tetapi, dengan corporate governance yang baik akan berdampak pada penerapan sistem pengawasan (monitoring) tinggi dan efisien sehingga penetapan mengenai kompensasi akan menjadi lebih terbuka. Dengan demikian, dapat disimpulkan bahwa corporate governance yang diproksikan dengan IND dan INS tidak berpengaruh positif signifikan terhadap kompensasi eksekutif.

Variabel gender yang diukur dengan variabel dummy memiliki hubungan negatif dan tidak 


\section{Pengaruh Kinerja Perusahaan, Corporate Governance, dan Karakteristik Eksekutif terhadap Kompensasi Eksekutif}

Suherman, Yoseph Y. P. Pardede, \& U mi Mardiyati

signifikan terhadap kompensasi eksekutif dalam sebuah perusahaan. Hal ini terlihat dari nilai koefisien sebesar -0,154 pada persamaan I, -0,162 pada persamaan $\mathrm{V}$ dan $-0,157$ pada persamaan $\mathrm{VI}$ dengan nilai probabilitas stat pada persamaan I sebesar 0,29; 0,26 pada persamaan $V$ dan 0,27 pada persamaan VI. Spiropoulos, et al. (2012) menemukan hasil yang sama bahwa gender dalam dewan eksekutif tidak memiliki pengaruh signifikan terhadap kompensasi eksekutif dalam sebuah perusahaan. Hal ini terjadi karena jika sebuah perusahaan mengurangi kesenjangan gender dalam memberikan kompensasi terhadap eksekutifnya adalah sebuah tanda bahwa perusahaan tersebut memiliki better functioning market untuk dewan eksekutifnya.

Usia yang diukur dari rata-rata tahun kelahiran dari dewan eksekutif tidak terbukti memiliki hubungan yang positif signifikan terhadap kompensasi yang diterima eksekutif dalam sebuah perusahaan. Hal ini bisa dilihat dari nilai koefisien dari persamaan I, IV dan VI sebesar 0,025; 0,027 dan 0,025 dengan nilai probabilitas stat sebesar 0,32 pada persamaan I, 0,30 pada persamaan IV dan pada persamaan VI sebesar 0,34. H asil yang sama juga diperoleh Bouvier (2010) bahwa usia dari dewan eksekutif bukanlah faktor yang mempengaruhi secara signifikan terhadap struktur kompensasi eksekutif, karena faktor usia bukanlah hal yang bisa menjadi bahan pertimbangan bagi perusahaan dalam menentukan kompensasi. Hal yang sama juga diungkapkan Nulla (2014) bahwa usia eksekutif tidak memiliki pengaruh yang signifikan terhadap kompensasi yang diterima eksekutif perusahaan dikarenakan semakin bertambahnya usia eksekutif tidak mencerminkan pembayaran yang akan diterima, tetapi dilihat dari kinerja dan kontribusinya yang diberikan perusahaan.

Untuk variabel kontrol yaitu Size (ukuran perusahaan) yang diukur menggunakan total aset terbukti memiliki pengaruh positif dan signifikan terhadap kompensasi, hal ini terlihat dari koefisien
Size yang menunjukkan angka positif signifikan dengan nilai koefisien sebesar 0,674 pada persamaan I; 0,662. Hal ini dikarenakan Size yang diproksikan dengan total penjualan berpengaruh positif signifikan terhadap besarnya kompensasi yang diterima eksekutif dalam sebuah perusahaan (Devi, 2012). Menurut Partasarathy, et al. (2006) ukuran perusahaan dengan menggunakan pengukuran total sales memiliki hubungan yang searah dengan besarnya kompensasi yang diterima eksekutif. Perusahaan besar akan memiliki inventory yang besar jugauntuk dijadikan pemasukan perusahaan. Perusahaan dengan sales yang besar maka akan memperoleh profit yang besar. Semakin besar profit maka semakin besar juga ukuran perusahaan serta memiliki kemampuan untuk membayar eksekutif dalam jumlah yang besar.

\section{KESIM PULAN DAN SARAN}

Topik kompensasi sampai sekarang masih menarik untuk diteliti. Penelitian ini bertujuan untuk mengetahui pengaruh kinerja perusahaan, tata kelola perusahaan dan karakteristik eksekutif terhadap kompensasi yang diterima oleh eksekutif. Dapat dikatakan bahwa pengaruh kinerja perusahaan terhadap kompensasi masih mixed; bisa signifikan atau tidak signifikan tergantung pada pengukurannya. Sedangkan corporate governance (tata kelola perusahaan) tidak memiliki pengaruh signifikan terhadap kompensasi eksekutif. Karakteristik eksekutif juga tidak mempunyai pengaruh signifikan terhadap kompensasi eksekutif. Lebih jauh, total aset (ukuran perusahaan) sebagai variabel kontrol memiliki pengaruh positif signifikan terhadap kompensasi eksekutif perusahaan.

Penelitian berikutnya dapat memperluas model penelitian ini dengan menginvestigasi adanya saling pengaruh antara kinerja dan kompensasi eksekutif (apakah kinerja pengaruhi kompensasi atau kompensasi pengaruhi kinerja). 


\section{Jurnal Keuangan dan Perbankan | KEUANGAN}

Vol. 20, N o.1, Januari 2016: 1-9

\section{DAFTAR PUSTAKA}

Andarini, P. dan Januarti, Indira. 2012. Hubungan Karakteristik Dewan Komisaris dan Perusahaan Terhadap Keberadaan Komite Manajemen Risiko Pada Perusahaan Go Public di Indonesia. Jurnal A kuntansi dan Keuangan Indonesia, vol. 9, no.1, p. 83-99.

Anggraini, Silvia., Yunilma dan Fauziati, Popi. 2014. Faktor-Faktor Yang Mempengaruhi Pemberian Kompensasi Kepada Dewan Direksi Perusahaan Yang Go Public Di Indonesia. E-Jurnal U niversitas Bung Hatta, vol. 4, no. 1, pp. 1-13.

Ayadi, N. dan Boujèl bène, Y. 2013. The Influence of the Board of Directors on the Executive Compensation in the Banking Industry, Global Business \& $M$ anagement Research: $A n$ International Journal, vol. 5, no. $2 \&$ 3, hal. 83-90.

Bizjak, J., Hayes, Rachel M. dan Kalpathy, S. 2013. Performance-Contingent Executive Compensation and Firm Earnings. Diunduh dari internet http:/ / ssrn.com pada tanggal 21 Februari 2015, hal. 144.

Boone, L.E dan Kurtz, D. L. 2007. Pengantar Bisnis Kontemporer, edisi 11. Jakarta: Sal emba Empat.

Bouvier, Anthony. 2010. The Effect of Age upon CEO Compensation: A Cross-Industry Study. Diunduh dari internet http:/ / scholarship.claremont.edu/ cmc theses/ 11 pada tanggal 24 Februari 2015.

Colpan, A. dan Yoshikawa, T. 2012. Performance Sensitivity of ExecutivePay: The Role of Foreign Investor and Affiliated Directors in Japan. An International Review Journal, vol. 20, no.6, hal. 547-561.

Conyon, M. dan He, L. 2011. Executive Compensation and Corporate Governance in China, Journal of Corporate Finance.

Croci, E., Gonenc, H. dan Ozkan, N. 2012. CEO Compensation, Family Control, and Institutional investors in continental Europe, Journal of Banking \& Finance.

Darmadi, Salim. 2011. The Determinants of Board Compensations: Evidence from Indonesia. The Indone sian Journal of Accounting Research, vol. 14, no. 2, hal. 1-42.

Devi, Monica S. 2012. Pengaruh Kinerja Perusahaan, Corporate Governance, dan Shareholder Payout
Terhadap Kompensasi Eksekutif Perusahaan Non Financial yang Listing di BEI antara tahun 2007201. Jurnal Riset $M$ anajemen Sains Indonesia, vol. 4, no. 2 , hal. 167-183.

Diaz, M. dan Espa, V. 2008. Bentuk dan Komponen Penentu Kompensasi Eksekutif. Jurnal Tema U niversitas Brawijaya, vol. 9, no. 1, Maret 2008, pp. 6777.

Gabaix, X., Landier, A. dan Sauvagnat, J. 2013. CEO Pay and Firm Size: An Update after theCrisis. The Economic Journal $\mathrm{N}$ ew $\mathrm{Y}$ ork U niversity, vol. 124, iss. 574, hal. 1-36.

Lee, Shin-Ping dan Chen, Hui-Ju. 2011. Corporate Governance and firm value as determinants of CEO compensation in Taiwan. $M$ anagement Research Review Journal, vol. 34, no. 3, pp. 252-265.

Lin, Dan dan Lu Lin. 2014. The Interplay between Director Compensation and CEO Compensation, The International Journal of Business and Financeresearch, vol. 8, no. 2, hal. 11-26.

Nathania, A ditha. 2014. Pengaruh Komposisi Dewan Perusahaan Terhadap Profitablitas Perusahaan, Student Journals Petra Christian U niversity, vol. 2, no. 1, hal. 76-81.

Nourayi, M., Kal bers, L. dan Daroca, Frank P. 2012. The Impact of Corporate Governance And The Sarbanes-Oxley Act on CEO Compensation, Journal of A pplied Business Research, vol. 28, no. 3, hal. 463-479.

Nuh, Muchammad. 2013. Pengaruh Reformasi Birokrasi Terhadap Produktivitas Tenaga Kerja Sektor Publik. Jurnal IImiah U niversitas Brawijaya. Diunduh dari internet http:/ / jimfeb.ub.ac.id/ pada tanggal 15 Maret 2015.

Nulla, M. Yusuf. 2014. The effect of CEO Age on CEO Compensation Using Accounting Performance as a Benchmark: An empirical study on NYSE Index companies. Journal of $\mathrm{M}$ anagement $\mathrm{P}$ olicies and Practices, vol. 2, no. 1, hal. 119-133.

Ozdemir, Ozgur. dan Upneja, Arun. 2012. Board Structure and CEO Compensation: Evidence from U.S. lodging industry. International Journal of $\mathrm{H}$ ospitality $\mathrm{M}$ anagement, vol. 31, iss. 3, pp. 856-863.

Parthasarathy, A., Menon, K. dan Bhattacherjee, D. 2006. Executive Compensation, Firm Performance, and 


\section{Pengaruh Kinerja Perusahaan, Corporate Governance, dan Karakteristik Eksekutif terhadap Kompensasi Eksekutif}

Suherman, Yoseph Y. P. Pardede, \& Umi Mardiyati

Corporate Governance: An Empirical Analysis. Diunduh dari internet http:/ / ssrn.com/ pada tanggal 21 Februari 2015)

Rahmawati, Wulan. 2010. Pengaruh Kinerja Perusahaan, Ukuran Perusahaan dan Mekanisme Corporate Governance Terhadap Kompensasi Eksekutif Perusahaan Keuangan yang Listing di BEI antara tahun 2007-2009. Skripsi Universitas Negeri Jakarta.

Rashid, Afzalur. 2013. Corporate Governance, Executive Pay and Firm Performance: Evidence from Bangladesh. International Journal of $M$ anagement, vol. 30, no. 2, hal. 556-575.

Sands, Kathleen. 2014. CEO Compensation: A Position Paper. Johnson and Wales University. Diunduh dari internet http:/ / scholarsarchive.jwu.edu pada tanggal 28 Februari 2014.

Scott, W. R. 2003. Financial A ccounting Theory. Pearson: Education Canada Inc.

Spiropoulos, H., Matolesy, Z dan Bugeja, Martin. 2012. Is there a gender gap in CEO Compensation?. Journal of Corporate Finance, vol. 18, iss. 4, hal. 849-859.

Sudarsono, Rachmat. 2002. Kompensasi Manajemen dan Kinerja: Upaya Pengendalian Agency Conflict, Jurnal A dministrasi Bisnis, vol. 2, no. 3/ 4/ 5, hal. 3536.
Suherman, Fitriawan, R., Ahmad, G. N. 2015. Pengaruh Kinerja Perusahaan, Kepemilikan Institusi, dan Komisaris Independen Terhadap Total Kompensasi: Studi pada Perusahaan Yang Terdaftar di LQ45 tahun 2009-2012, Jurnal A plikasi M anajemen, vol. 13, no. 3, hal.516-526.

Sun, Fang., Wei, Xiangjing dan Huang, Xue. 2013. CEO Compensation and Firm Performance Evidence from the US Property and Liability Insurance Industry, Review of A ccounting and Finance Journal, vol. 12, no. 3, hal. 252-267.

Vidyatmoko, D., Sanim, B., Siregar, H. dan Didu, M Said. 2013. Faktor-Faktor Yang Mempengaruhi Kompensasi Eksekutif dan Dampaknya terhadap Kinerja BUMN Perkebunan. Indonesian Journal for the Science of M anagement, vol. 12, no. 2, hal 115128.

Wang, LieHuey., Kuo, Hsien-Chang dan Lin, Dan. 2013. Chief Executive Compensation: An Empirical Study of Fat Cat CEOs, The International Journal of Business and Finance Research, vol. 7, no. 2, hal. 2742.

Xiao, Z., He, Rui., Lin, Zhangxi dan Elkins, H. 2013. CEO Compensation in China: A ccounting Performance, corporate governance, and the gender gap, $N$ ankai Business Review International Journal, vol. 4, no. 4, hal. 309-328. 